\title{
Studi Kualitas Pelayanan dari Segi Fasilitas dan Operasional di Universitas Al Azhar Indonesia (Sebuah Studi Kasus)
}

\author{
Niken Parwati ${ }^{*}$, Dinda Mutia Ramli \\ Program Studi Teknik Industri, Fakultas Sains dan Teknologi, \\ Universitas Al Azhar Indonesia, Jl. Sisingamangaraja, Jakarta 12110 \\ *Penulis untuk Korespondensi: niken.parwati@uai.ac.id
}

Abstrak - Universitas Al Azhar Indonesia (UAI) selalu berusaha meningkatkan kualitas pelayanannya baik dari segi operasional maupun penyediaan fasilitasnya. Studi ini dilakukan untuk mengetahui keinginan pelanggan (dalam hal ini mahasiswa) mengenai harapan dan kinerja pelayanan UAI yang diterima mahasiswa selama ini. Studi ini dimulai dengan dibuatnya pemetaan service blueprint yang dialami mahasiswa dalam menghadapi pelayanan di UAI. Setelah itu dilakukan survei langsung wawancara dalam bentuk pra kuesioner. Berdasarkan dari hasil pra kuesioner dibuatlah kuesioner. Berdasarkan data yang diperoleh ini kuesioner ini dilakukan perhitungan dan dibuatlah model Service Quality (ServQual) dan Quality Function Deployment (QFD). Berdasarkan hasil analisis terhadap kedua model, didapatkan atribut layanan yang perlu mendapatkan prioritas untuk meningkatkan kualitas jasa layanan di UAI secara berurutan yaitu: (1) meja dan kursi kuliah yang nyaman, (2) dosen komunikatif dalam proses perkuliahan, (3) adanya spanduk atau signage yang menunjukan adanya gedung UAI, (4) jumlah mahasiswa wanita, (5) panjang antrian di Bank, (6) kemudahan proses pembayaran, (7) jumlah meja dan kursi sesuai dengan pengunjung perpustakaan, (8) dosen memberikan penilaian secara objektif, (9) dosen dapat memberikan materi dengan baik dan jelas, (10) staf berpenampilan rapi, (11) dosen berpenampilan rapi saat kuliah, (12) nilai perkuliahan diumumkan secara terbuka dan diberitahukan dengan rinci, (13) sistem pembayaran semesteran yang lebih praktis (misalnya melalui ATM), (14) jumlah toilet untuk mahasiswa pria, (15) kemudahan proses mendaftar.
Abstract - University of Al Azhar Indonesia (UAI) is attempting to increase their services quality at operational and facility level. This study is conducted to obtain customer perception (in this case the student) about UAI performance versus the student's expectancy. The study began with mapping operational procedure in service blueprint which become as basis of generating questionnaires. To analyze the result, Service Quality (ServQual) and Quality Function Deployment (QFD) are modeled. From the two models analysis results, the priority attributes to enhance the service quality in UAI are (1) table and chair coziness, (2) lecturers' communication quality, (3) visibility of UAI banner and signage, (4) number of women restrooms, (5) length of queue in the bank, (6) simplicity of tuition payment procedure, (7) number of table and chair in the library, (8) lecturers' grading objectivity, (9) lecturers'clarity in delivering their material, (10) employees code of dress (properly and neatly), (11) lecturers' code of dress (tidiness), (12) student grades are announce openly in detail, (13) more practical tuition payment system (e.g using ATM), (14) number of men restrooms, (15) admission procedur simplicity.

Keyword - Performance versus Expetancy, Service Blue Print, Service Quality, Quality Function Deployment

\section{PENDAHULUAN}

$\mathrm{U}$ niversitas Al Azhar Indonesia merupakan lembaga pendidikan yang bergerak di bidang jasa yang mempunyai tujuan untuk memberikan pengetahuan menyeluruh terhadap ilmu yang diminati oleh mahasiswa yang bersangkutan. Untuk itu kualitas layanan yang diterima baik dari segi 
akademik ataupun non akademik, serta fasilitas merupakan faktor yang menentukan dalam keberhasilan mahasiswa itu sendiri dan Universitas yang bersangkutan. Mahasiswa yang merasa puas terhadap pelayanan yang diberikan Universitas akan mempunyai kecenderungan untuk menjadi mahasiswa yang loyal yang selalu membanggakan almamaternya dan diharapkan akan merekomendasikan Universitasnya ke calon mahasiswa baru. Oleh karena itu, Universitas dituntut untuk meningkatkan kualitas penyampaian produk dan layanannya.

Oleh karena itu dilakukan penelitian dengan menggunakan metode Service Quality (ServQual) dan Quality Function Deployment (QFD). Pendekatan ServQual digunakan untuk menentukan atribut, dan mengukur kesenjangan (gap) antara harapan dengan persepsi konsumen terhadap suatu pelayanan. Kemudian QFD digunakan untuk merancang perbaikan kualitas pelayanan sesuai dengan kebutuhan yang diinginkan oleh mahasiswa serta kemampuan Universitas. Penelitian dengan metode ini diharapkan dapat meningkatkan kualitas layanan sesuai dengan harapan mahasiswa.

\section{TINJAUAN PUSTAKA}

\subsection{Service Blueprint}

Istilah lain untuk service blueprint adalah service mapping atau service flowchart. Pada prinsipnya, service blueprint merupakan skema grafis visual yang bisa membantu para manajer jasa untuk mendapatkan gambaran holistik tentang jasa dan layanannya serta memperoleh wawasan manajerial mengenai karakteristik pengalaman pelanggan. Dalam merancang sebuah service blueprint, organisasi jasa harus menggunakan perspektif pelanggan, sehingga urutan-urutan proses yang didokumentasikan mencerminkan tahap-tahap yang dilalui pelanggan dalam mendapatkan layanan atau jasa yang dikehendaki. Setiap tahap mencakup aspek visible dan invisible penyampaian jasa kepada pelanggan.

\subsection{Quality Function Deployment}

QFD merupakan suatu metode yang digunakan perusahaan untuk mengantisipasi dan menentukan prioritas kebutuhan dan keinginan konsumen, serta menggabungkan kebutuhan dan keingingan konsumen tersebut dalam produk dan jasa yang disediakan bagi konsumen. Suatu organisasi yang mengimplementasikan QFD dengan tepat, dapat meningkatkan pengetahuan rekayasa, kualitas dan mengurangi ongkos, waktu pengembangan produk, serta perubahan-perubahan rekayasa.

QFD adalah metode terstruktur yang digunakan dalam proses perencanaan dan pengembangan produk untuk menetapkan spesifikasi kebutuhan dan keinginan konsumen, serta mengevaluasi serta sistematis kapabilitas suatu produk atau jasa dalam memenuhi kebutuhan dan keinginan konsumen. [1]

\section{Menyusun Rumah Kualitas}

Penerapan metode QFD dalam proses perancangan produk dan jasa diawali dengan pembentukan matriks perencanaan produk atau sering disebut sebagai House of Quality (rumah kualitas). Gambaran umum matriks perencanaan atau rumah kualitas, dalam gambar ini digunakan simbol huruf A hingga $F$ yang menunjukkan urutan pengisian bagian-bagian dari matriks perencanaan tersebut.

Bagian I: Berisi data atau informasi mengenai hasil penelitian pasar tentang kebutuhan dan keinginan konsumen.

Bagian II: Berisi tiga jenis data yaitu pertama tingkat kepentingan dan kebutuhan dan keinginan konsumen, kedua data kepuasan konsumen terhadap produk atau jasa yang dihasilkan oleh perusahaan dan produk pesaing, ketiga tujuan strategis untuk produk dan jasa baru yang akan dikembangkan.

Bagian III: Berisi persyaratan-persyaratan teknis untuk produk atau jasa baru yang akan dikembangkan. Data ini diturunkan berdasarkan informasi yang diperoleh mengenai kebutuhan dan keinginan konsumen (matriks A).

Bagian IV: Berisi penilaian manajemen mengenai kekuatan hubungan antara elemen-elemen yang terdapat pada bagian persyaratan teknis (matriks C) terhadap kebutuhan konsumen (matriks A) yang dipengaruhinya. Kekuatan hubungan dinyatakan dengan menggunakan simbol tertentu.

Bagian V: Menunjukkan korelasi antar persyaratan teknis yang satu dengan persyaratan-persyaratan teknis yang lain yang terdapat dalam matriks $\mathrm{C}$. korelasi antara kedua persyaratan teknis tersebut ditunjukkan dengan menggunakan simbol-simbol tertentu. 
Bagian VI: Berisi tiga jenis data, yaitu: (1) urutan tingkat kepentingan persyaratan teknis, (2) informasi hasil perbandingan kinerja persyaratan teknis produk/jasa yang dihasilkan oleh perusahaan terhadap kinerja produk pesaing, (3) target kinerja persyaratan teknis produk/jasa yang baru dikembangkan.

\subsection{Metode ServQual}

Kualitas layanan dapat di definisikan sebagai segala sesuatu yang memfokuskan pada usaha untuk memenuhi kebutuhan dan keinginan konsumen yang disertai dengan ketepatan dalam menyampaikannya, sehingga tercipta kesesuaian yang seimbang dengan harapan konsumen.

[2] mengembangkan suatu alat untuk mengukur kualitas layanan dalam bentuk metodologi yang dinamakan ServQual (Service Quality). ServQual ini terdiri atas dua bagian, yaitu:

a. Bagian Harapan yang berisi pertanyaan untuk mengetahui harapan umum dari konsumen atau pelanggan yang berkaitan dengan jasa.

b. Bagian Persepsi yang berisi pertanyaan yang sama dengan bagian harapan untuk mengukur penilaian konsumen atau pelanggan terhadap perusahaan yang di teliti.

Setiap pertanyaan yang baik pada bagian ekspektasi maupun persepsi diikuti skala yang terdiri dari tujuh derajat kepentingan, mulai dari angka 1 (Sangat Tidak Setuju) sampai angka 5 (Sangat Setuju Sekali). Responden harus memberikan satu penilaian saja untuk setiap pertanyaan dengan cara memilih satu diantara kelima angka tersebut.

Langkah-langkah selanjutnya adalah memberi penilaian pada masing-masing bagian, baik bagian harapan maupun bagian persepsi yang di lakukan melalui pembagian kuesioner kepada responden. Hasil penilaian responden kemudian dihitung selisihnya, untuk mengetahui nilai ServQual. Dari hasil perhitungan tersebut ada tiga kemungkinan, yaitu :

a. Jika positif (+), berarti harapan konsumen atau pelanggan terlampaui yang menunjukkan semakin baik kualitas perusahaan tersebut di mata konsumen atau pelanggan.

b. Jika nol (0), berarti harapan konsumen atau pelanggan terpenuhi.

c. Jika negatif (-), berarti perusahaan tersebut masih belum mampu memenuhi harapan konsumen atau pelanggan.

\section{METODE PENELITIAN}

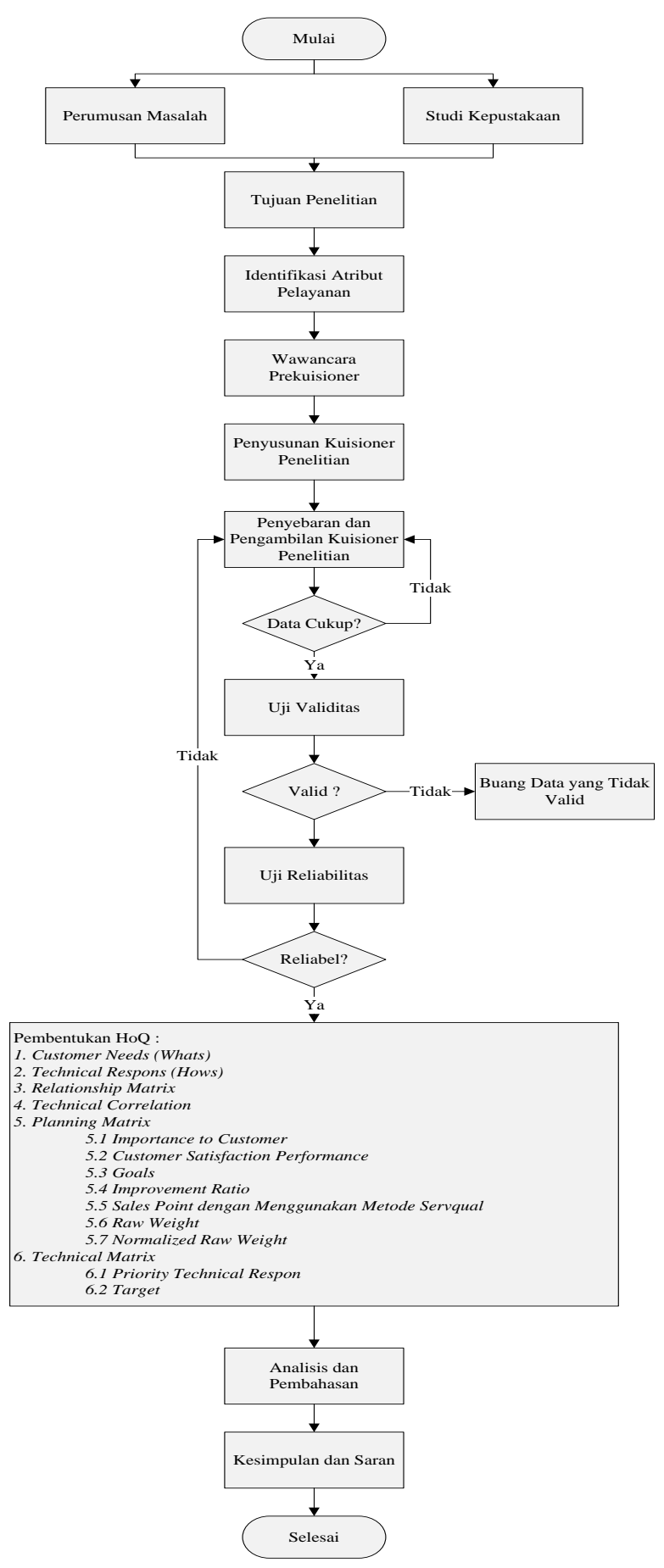

Gambar 1. Metodologi Penelitian 


\section{HASIL DAN PEMBAHASAN}

\subsection{Uji Kecukupan Data}

Berdasarkan data yang diberikan pihak UAI bahwa jumlah mahasiswa aktif pada tahun ajaran 2010/2011 adalah sebesar 2.972 mahasiswa. Penetapan jumlah sampel yang akan diambil mengacu pada pendapat Slovin yang dirumuskan sebagai berikut:

$$
\mathrm{n}=\frac{\mathrm{N}}{1+\left(N e^{2}\right)}
$$

dimana, $\mathrm{N}=2.972$ mahasiswa dan $\mathrm{e}=10 \%$

$$
\mathrm{n}=\frac{2.972}{1+\left(2.972 \times(0,1)^{2}\right)}=96,74 \approx 100
$$

\subsection{Uji Validitas dan Reliabilitas}

Uji ini dilakukan untuk data-data yang berasal dari kuisioner penelitian yang berisi mengenai harapan dan kepuasan pelanggan (mahasiswa) terhadap operasional (layanan) dan fasilitas.

Berdasarkan hasil uji validitas untuk variabel harapan dan kinerja dengan 100 responden dan angka r-kritis 0,197 (taraf signifikansi sebesar 5\%) maka dapat diketahui bahwa terdapat 36 data (pertanyaan kuisioner) valid. Berikut merupakan hasil uji reliabilitas data kuisioner penelitian dengan 100 responden, taraf signifikasi 5\% dan $\mathrm{r}=$ 0,197 .

Tabel 1. Output Realibilitas Harapan

\begin{tabular}{cr}
\hline Variabel & \multicolumn{1}{c}{ Nilai } \\
\hline $\mathrm{S}_{\mathrm{t}}{ }^{2}$ & 182.394 \\
$\mathrm{~S}_{\mathrm{i}}{ }^{2}$ & 154.284 \\
$\mathrm{r}_{\mathrm{i}}$ & 0,9408 \\
\hline
\end{tabular}

Tabel 2. Output Reliabilitas Kinerja

\begin{tabular}{cc}
\hline Variabel & Nilai \\
\hline $\mathrm{S}_{\mathrm{t}}{ }^{2}$ & 378.722 \\
$\mathrm{~S}_{\mathrm{i}}{ }^{2}$ & 407.712 \\
$\mathrm{r}_{\mathrm{i}}$ & 0,91713 \\
\hline
\end{tabular}

Untuk uji reliabilitas data variabel harapan menunjukan angka sebesar 0,941, sedangkan untuk variabel kinerja menunjukan angka sebesar 0,917. Dengan 100 responden dan taraf signifikan sebesar 5\%, maka dapat diketahui bahwa angka kritik nilai r sebesar 0,197. Hal ini menunjukan bahwa data yang digunakan pada penelitian ini reliable dan layak untuk dianalisa lebih lanjut.

Setelah dilakukan uji kelayakan data, langkah selanjutnya adalah menentukan selisih antara kinerja perusahaan dan harapan pelanggan. Selisih tersebut berguna untuk mengetahui apakah pelanggan merasa puas atau tidak puas dengan pelayanan yang diberikan oleh perusahaan.

Dari nilai Tabel 5 pada lampiran dapat dilihat bahwa nilai gap terbesar terdapat pada atribut nomor 34 dengan nilai $-1,93$ yaitu jumlah meja dan kursi di kantin memadai kemudian nilai gap terkecil terdapat pada atribut nomor 4 dengan nilai $-0,58$ yaitu dosen berpenampilan rapi saat kuliah. Nilai gap menunjukan tingkat kepuasan mahasiswa. Semakin besar nilai minus suatu gap menunjukan pelanggan semakin tidak puas atas pelayanan yang diberikan oleh perusahaan dan sebaliknya.

Setelah perhitungan gap selesai dilakukan, langkah selanjutnya adalah menjabarkan kebutuhan pelanggan ke dalam respon teknis. Penjabaran ini bertujuan untuk mengisi data-data dalam pembuatan rumah kualitas.

Setelah melakukan penjabaran antara kebutuhan pelanggan dan respon teknis, serta melakukan perhitungan lainnya seperti yang dijelaskan didalam metodologi penelitian, selanjutnya dilakukan perhitungan untuk membuat HoQ seperti yang disajikan pada Gambar 2 pada lampiran.

\section{KESIMPULAN}

1. Berdasarkan urutan prioritas tingkat kepentingan (importance to customer), maka dapat diketahui sebanyak 36 atribut yang dipentingkan oleh mahasiswa dan tingkat kepentingan ini merupakan harapan mahasiswa yang sangat perlu diperhatikan oleh pihak manajemen UAI. Secara berurutan 10 nilai tertinggi atribut pelayanan tersebut adalah sebagai berikut: (1) Staf memberikan informasi dengan lengkap dan jelas, (2) Tersedia LCD/OHP yang layak dipakai saat kuliah, (3) 
Dosen komunikatif saat proses perkuliahan, (4) Mudah mendapatkan materi perkuliahan, (5) Tersedia perpustakaan yang nyaman dan bersih, (6) Meja dan kursi kuliah yang nyaman, (7) Tersedia ruang kelas yang sesuai dengan jumlah mahasiswa, (8) Tersedia ruang diskusi yang nyaman dan (meja dan kursi) yang memadai, (9) Jumlah toilet mencukupi untuk mahasiswa wanita, (10) Tersedia kantin yang bersih.

2. Berdasarkan urutan, nilai gap yang paling besar terdapat pada atribut nomor 8 pada dimensi tangibles dengan nilai $-1,93$ "jumlah meja dan kursi di kantin memadai" hal ini menunjukan bahwa mahasiswa tidak puas dengan kualitas dan kuantitas jumlah meja dan kursi yang ada di kantin. Sedangkan nilai gap paling kecil terdapat pada atribut nomor 1 pada dimensi assurance dengan nilai $-0,58$ "dosen berpenampilan rapi saat kuliah" hal ini menunjukan bahwa mahasiswa cukup puas dengan penampilan dosen saat kegiatan belajar mengajar berlangsung.

3. Berdasarkan hasil akhir perhitungan Raw Weight peneliti membagi 15 atribut yang perlu mendapatkan perhatian lebih diantara atribut lainnya, diantaranya adalah: (1) Meja dan kursi kuliah yang nyaman, (2) Dosen komunikatif dalam proses perkuliahan, (3) Adanya spanduk atau signage yang menunjukan adanya gedung
UAI, (4) Jumlah mahasiswa wanita, (5) Panjang antrian di Bank, (6) Kemudahan proses pembayaran, (7) Jumlah meja dan kursi sesuai dengan pengunjung perpustakaan, (8) Dosen memberikan penilaian secara objektif, (9) Dosen dapat memberikan materi dengan baik dan jelas, (10) Staf berpenampilan rapi, (11) Dosen berpenampilan rapi saat kuliah, (12) Nilai perkuliahan diumumkan secara terbuka dan diberitahukan dengan rinci, (13) Sistem pembayaran semesteran yang lebih praktis (misalnya melalui ATM), (14) Jumlah toilet untuk mahasiswa pria, (15) Kemudahan proses mendaftar. Atribut ini merupakan atribut prioritas yang perlu diperbaiki dengan segera, sehingga kepuasaan mahasiswa atas operasional dan fasilitas dapat tercapai dengan baik.

\section{DAFTAR PUSTAKA}

[1] Cohen, Lou, 1995, Quality Function Deployment : How Make QFD For You, Addison Wasley Publishing Company, Massachusetts.

[2] Parasuraman, A., L.L. Berry, and V.A Zeithaml. 1991. "Refinement and Reassessment of the SERVQUAL Scale", Journal of Retailing, vol.67 No.4 (Winter), pp. $41-50$. 


\section{Lampiran}

Tabel 3. Angka Korelasi dari Uji Validitas Harapan

\begin{tabular}{|c|c|c|c|}
\hline No & Dimensi Kualitas & p - Value & Status \\
\hline \multicolumn{4}{|c|}{ Tangibles } \\
\hline 1 & Adanya spanduk atau signage yang menunjukan adanya gedung UAI & 0,382 & valid \\
\hline 2 & Meja dan kursi kuliah yang nyaman & 0,677 & valid \\
\hline 3 & Jumlah meja dan kursi sesuai dengan pengunjung perpustakaan & 0,733 & valid \\
\hline 4 & Koleksi buku untuk setiap program studi lengkap & 0,733 & valid \\
\hline 5 & $\begin{array}{l}\text { Ada perpustakaan yang dapat diakses lewat internet sehingga } \\
\text { memudahkan mahasiswa mencari data yang diperlukan }\end{array}$ & 0,699 & valid \\
\hline 6 & Jumlah toilet mencukupi untuk mahasiswa pria & 0,217 & valid \\
\hline 7 & Jumlah toilet mencukupi untuk mahasiswa wanita & 0,358 & valid \\
\hline 8 & Jumlah meja dan kursi di kantin memadai & 0,706 & valid \\
\hline 9 & Makanan dan minuman yang ada di kantin bervariasi & 0,586 & valid \\
\hline \multicolumn{4}{|c|}{ Realibility } \\
\hline 1 & Proses mendaftar mudah & 0,462 & valid \\
\hline 2 & Proses pembayaran mudah & 0,455 & valid \\
\hline 3 & Pembayaran dapat ditransfer lewat ATM / antar Bank & 0,488 & valid \\
\hline 4 & Tidak ada antrian di Bank & 0,797 & valid \\
\hline 5 & Proses menginput mata kuliah untuk semester berikutnya mudah & 0,724 & valid \\
\hline 6 & Tidak ada antrian di saat menginput mata kuliah & 0,753 & valid \\
\hline 7 & Nilai diberitahukan dengan rinci & 0,641 & valid \\
\hline 8 & Mudah dalam mendapatkan materi perkuliahan & 0,614 & valid \\
\hline 9 & Ruang dan waktu kuliah konsisten & 0,684 & valid \\
\hline 10 & $\begin{array}{l}\text { Ada pemberitahuan sebelumnya bila perkuliahan ditiadakan atau } \\
\text { diundur }\end{array}$ & 0,592 & valid \\
\hline \multicolumn{4}{|c|}{ Responsiveness } \\
\hline 1 & Dosen dapat memberikan materi dengan baik dan jelas & 0,354 & valid \\
\hline 2 & Dosen komunikatif dalam proses perkuliahan & 0,425 & valid \\
\hline 3 & Staf memberikan informasi dengan lengkap dan jelas & 0,688 & valid \\
\hline 4 & Staf melakukan pekerjaannya dengan cepat & 0,418 & valid \\
\hline \multicolumn{4}{|c|}{ Assurance } \\
\hline 1 & Dosen berpenampilan rapi saat kuliah & 0,309 & valid \\
\hline 2 & Staf berpenampilan rapi saat kuliah & 0,416 & valid \\
\hline 3 & Tersedia LCD / OHP yang layak untuk dipakai saat kuliah & 0,699 & valid \\
\hline 4 & Tersedia ruang kelas yang sesuai dengan jumlah mahasiswa & 0,679 & valid \\
\hline 5 & $\begin{array}{l}\text { Tersedia Air Conditioning (AC) yang selalu beroperasi dengan baik } \\
\text { di ruang kelas }\end{array}$ & 0,620 & valid \\
\hline 6 & Tersedia perpustakaan nyaman dan bersih & 0,620 & valid \\
\hline 7 & Tersedia ruang diskusi yang nyaman dan (meja dan kursi) memadai & 0,704 & valid \\
\hline 8 & Tersedia toilet yang bersih & 0,702 & valid \\
\hline 9 & Tersedia kantin yang bersih & 0,782 & valid \\
\hline
\end{tabular}




\begin{tabular}{|c|l|c|c|}
\hline No & \multicolumn{1}{|c|}{ Dimensi Kualitas } & p-Value & Status \\
\hline 10 & Tersedia hotspot untuk akses internet & 0,537 & valid \\
\hline \multicolumn{2}{|c|}{ Emphaty } \\
\hline 1 & Dosen memberikan penilaian secara objektif & 0,449 & valid \\
\hline 2 & Staf melayani mahasiswa dengan tanggap dan ramah & 0,631 & valid \\
\hline 3 & $\begin{array}{l}\text { Bila ada permasalahan, staf bersedia membantu hingga } \\
\text { permasalahan tersebut selesai }\end{array}$ & 0,598 & valid \\
\hline
\end{tabular}

Tabel 4. Angka Korelasi Dari Uji Validitas Kinerja

\begin{tabular}{|c|c|c|c|}
\hline No & Dimensi Kualitas & p - Value & Status \\
\hline \multicolumn{4}{|c|}{ Tangibles } \\
\hline 1 & Adanya spanduk atau signage yang menunjukan adanya gedung UAI & 0,327 & valid \\
\hline 2 & Meja dan kursi kuliah yang nyaman & 0,581 & valid \\
\hline 3 & Jumlah meja dan kursi sesuai dengan pengunjung perpustakaan & 0,443 & valid \\
\hline 4 & Koleksi buku untuk setiap program studi lengkap & 0,614 & valid \\
\hline 5 & $\begin{array}{l}\text { Ada perpustakaan yang dapat di akses lewat internet sehingga } \\
\text { memudahkan mahasiswa mencari data yang diperlukan }\end{array}$ & 0,675 & valid \\
\hline 6 & Jumlah toilet mencukupi untuk mahasiswa pria & 0,372 & valid \\
\hline 7 & Jumlah toilet mencukupi untuk mahasiswa wanita & 0,296 & valid \\
\hline 8 & Jumlah meja dan kursi di kantin memadai & 0,662 & valid \\
\hline 9 & Makanan dan minuman yang ada di kantin bervariasi & 0,577 & valid \\
\hline \multicolumn{4}{|c|}{ Realibility } \\
\hline 1 & Proses mendaftar mudah & 0,474 & valid \\
\hline 2 & Proses pembayaran mudah & 0,437 & valid \\
\hline 3 & Pembayaran dapat ditransfer lewat ATM / antar Bank & 0,553 & valid \\
\hline 4 & Tidak ada antrian di Bank & 0,600 & valid \\
\hline 5 & Proses menginput mata kuliah untuk semester berikutnya mudah & 0,536 & valid \\
\hline 6 & Tidak ada antrian di saat menginput mata kuliah & 0,629 & valid \\
\hline 7 & Nilai diberitahukan dengan rinci & 0,606 & valid \\
\hline 8 & Mudah dalam mendapatkan materi perkuliahan & 0,508 & valid \\
\hline 9 & Ruang dan waktu kuliah konsisten & 0,691 & valid \\
\hline 10 & $\begin{array}{l}\text { Ada pemberitahuan sebelumnya bila perkuliahan ditiadakan atau } \\
\text { diundur }\end{array}$ & 0,693 & valid \\
\hline \multicolumn{4}{|c|}{ Responsiveness } \\
\hline 1 & Dosen dapat memberikan materi dengan baik dan jelas & 0,349 & valid \\
\hline 2 & Dosen komunikatif dalam proses perkuliahan & 0,284 & valid \\
\hline 3 & Staf memberikan informasi dengan lengkap dan jelas & 0,378 & valid \\
\hline 4 & Staf melakukan pekerjaannya dengan cepat & 0,375 & valid \\
\hline \multicolumn{4}{|c|}{ Assurance } \\
\hline 1 & Dosen berpenampilan rapi saat kuliah & 0,275 & valid \\
\hline 2 & Staf berpenampilan rapi saat kuliah & 0,542 & valid \\
\hline
\end{tabular}




\begin{tabular}{|c|l|c|c|}
\hline No & \multicolumn{1}{|c|}{ Dimensi Kualitas } & p - Value & Status \\
\hline 3 & Tersedia LCD / OHP yang layak untuk dipakai saat kuliah & 0,324 & valid \\
\hline 4 & Tersedia ruang kelas yang sesuai dengan jumlah mahasiswa & 0,567 & valid \\
\hline 5 & $\begin{array}{l}\text { Tersedia Air Conditioning (AC) yang selalu beroperasi dengan baik di } \\
\text { ruang kelas }\end{array}$ & 0,484 & valid \\
\hline 6 & Tersedia perpustakaan nyaman dan bersih & 0,583 & valid \\
\hline 7 & Tersedia ruang diskusi yang nyaman dan (meja dan kursi) memadai & 0,638 & valid \\
\hline 8 & Tersedia toilet yang bersih & 0,558 & valid \\
\hline 9 & Tersedia kantin yang bersih & 0,590 & valid \\
\hline 10 & Tersedia hotspot untuk akses internet & 4,591 & valid \\
\hline \multicolumn{2}{|c|}{ Emphaty } & 0,529 & valid \\
\hline 1 & Dosen memberikan penilaian secara objektif & 0,560 & valid \\
\hline 2 & Staf melayani mahasiswa dengan tanggap dan ramah & 0,560 & valid \\
\hline 3 & $\begin{array}{l}\text { Bila ada permasalahan, staf bersedia membantu hingga permasalahan } \\
\text { tersebut selesai }\end{array}$ & & \\
\hline
\end{tabular}

Tabel 5. Hasil Perhitungan Customer Satisfaction Performance

\begin{tabular}{|c|c|c|c|c|}
\hline No & Dimensi Kualitas & Kinerja & Harapan & Gap \\
\hline \multicolumn{5}{|c|}{ Tangibles } \\
\hline 1 & Adanya spanduk atau signage yang menunjukan adanya gedung UAI & 3,86 & 5,10 & $-1,24$ \\
\hline 2 & Meja dan kursi kuliah yang nyaman & 3,66 & 4,76 & $-1,1$ \\
\hline 3 & Jumlah meja dan kursi sesuai dengan pengunjung perpustakaan & 3,26 & 4,55 & $-1,29$ \\
\hline 4 & Koleksi buku untuk setiap program studi lengkap & 2,83 & 4,59 & $-1,76$ \\
\hline 5 & $\begin{array}{l}\text { Ada perpustakaan yang dapat di akses lewat internet sehingga } \\
\text { memudahkan mahasiswa mencari data yang diperlukan }\end{array}$ & 2,94 & 4,65 & $-1,71$ \\
\hline 6 & Jumlah toilet mencukupi untuk mahasiswa pria & 3,92 & 4,47 & $-0,55$ \\
\hline 7 & Jumlah toilet mencukupi untuk mahasiswa wanita & 3,77 & 4,61 & $-0,84$ \\
\hline 8 & Jumlah meja dan kursi di kantin memadai & 2,72 & 4,65 & $-1,93$ \\
\hline 9 & Makanan dan minuman yang ada di kantin bervariasi & 2,92 & 4,48 & $-1,56$ \\
\hline \multicolumn{5}{|c|}{ Realibility } \\
\hline 1 & Proses mendaftar mudah & 3,68 & 4,48 & $-0,8$ \\
\hline 2 & Proses pembayaran mudah & 3,46 & 4,51 & $-1,05$ \\
\hline 3 & Pembayaran dapat ditransfer lewat ATM / antar Bank & 3,45 & 4,71 & $-1,26$ \\
\hline 4 & Tidak ada antrian di Bank & 2,81 & 4,51 & $-1,7$ \\
\hline 5 & Proses menginput mata kuliah untuk semester berikutnya mudah & 2,88 & 4,33 & $-1,45$ \\
\hline 6 & Tidak ada antrian di saat menginput mata kuliah & 2,76 & 4,5 & $-1,74$ \\
\hline 7 & Nilai diberitahukan dengan rinci & 3,38 & 4,5 & $-1,12$ \\
\hline 8 & Mudah dalam mendapatkan materi perkuliahan & 3,58 & 4,65 & $-1,07$ \\
\hline 9 & Ruang dan waktu kuliah konsisten & 2,94 & 4,55 & $-1,61$ \\
\hline 10 & $\begin{array}{l}\text { Ada pemberitahuan sebelumnya bila perkuliahan ditiadakan atau } \\
\text { diundur }\end{array}$ & 3,40 & 4,61 & $-1,21$ \\
\hline
\end{tabular}




\begin{tabular}{|c|c|c|c|c|}
\hline No & Dimensi Kualitas & Kinerja & Harapan & Gap \\
\hline \multicolumn{5}{|c|}{ Responsiveness } \\
\hline 1 & Dosen dapat memberikan materi dengan baik dan jelas & 4,07 & 4,83 & $-0,76$ \\
\hline 2 & Dosen komunikatif dalam proses perkuliahan & 3,75 & 4,72 & $-0,97$ \\
\hline 3 & Staf memberikan informasi dengan lengkap dan jelas & 3,03 & 4,6 & $-1,57$ \\
\hline 4 & Staf melakukan pekerjaannya dengan cepat & 2,97 & 4,52 & $-1,55$ \\
\hline \multicolumn{5}{|c|}{ Assurance } \\
\hline 1 & Dosen berpenampilan rapi saat kuliah & 3,63 & 4,21 & $-0,58$ \\
\hline 2 & Staf berpenampilan rapi saat bekerja & 3,43 & 4,39 & $-0,96$ \\
\hline 3 & Tersedia LCD / OHP yang layak untuk dipakai saat kuliah & 3,93 & 5,28 & $-1,35$ \\
\hline 4 & Tersedia ruang kelas yang sesuai dengan jumlah mahasiswa & 3,56 & 4,69 & $-1,13$ \\
\hline 5 & $\begin{array}{l}\text { Tersedia Air Conditioning (AC) yang selalu beroperasi dengan baik } \\
\text { di ruang kelas }\end{array}$ & 3,47 & 4,65 & $-1,18$ \\
\hline 6 & Tersedia perpustakaan nyaman dan bersih & 3,65 & 4,67 & $-1,02$ \\
\hline 7 & Tersedia ruang diskusi yang nyaman dan (meja dan kursi) memadai & 3,13 & 4,61 & $-1,48$ \\
\hline 8 & Tersedia toilet yang bersih & 2,95 & 4,53 & $-1,58$ \\
\hline 9 & Tersedia kantin yang bersih & 3,10 & 4,67 & $-1,57$ \\
\hline 10 & Tersedia hotspot untuk akses internet & 3,36 & 4,79 & $-1,43$ \\
\hline \multicolumn{5}{|c|}{ Emphaty } \\
\hline 1 & Dosen memberikan penilaian secara objektif & 3,65 & 4,60 & $-0,95$ \\
\hline 2 & Staf melayani mahasiswa dengan tanggap dan ramah & 2,82 & 4,46 & $-1,64$ \\
\hline 3 & $\begin{array}{l}\text { Bila ada permasalahan, staf bersedia membantu hingga } \\
\text { permasalahan tersebut selesai }\end{array}$ & 2,75 & 4,61 & $-1,86$ \\
\hline
\end{tabular}

Tabel 6. Penjabaran Customer Needs ke Dalam Technical Respon

\begin{tabular}{|c|c|c|}
\hline No & Customer Need & Technical Response \\
\hline 1 & Dosen dapat memberikan materi dengan baik dan jelas & Kinerja SDM \\
\hline 2 & Dosen komunikatif dalam proses perkuliahan & Kecakapan SDM \\
\hline 3 & Dosen memberikan penilaian secara objectif & Evaluasi Kerja \\
\hline 4 & Dosen berpenampilan rapi saat kuliah & Penampilan Karyawan \\
\hline 5 & Staf melayani mahasiswa dengan tanggap dan ramah & Kecakapan SDM \\
\hline 6 & Staf memberikan informasi dengan lengkap dan jelas & \multirow{2}{*}{ Kinerja SDM } \\
\hline 7 & Staf melakukan pekerjaannya dengan cepat & \\
\hline 8 & $\begin{array}{l}\text { Bila ada permasalahan staf bersedia membantu hingga } \\
\text { permasalahan tersebut selesai }\end{array}$ & Evaluasi Kerja \\
\hline 9 & Staf berpenampilan rapi & Penampilan Karyawan \\
\hline 10 & Proses mendaftar mudah & Kinerja SDM \\
\hline 11 & Proses pembayaran mudah & \multirow{5}{*}{ Kemudahan Proses } \\
\hline 12 & Pembayaran dapat ditransfer lewat ATM/antar bank & \\
\hline 13 & Tidak ada antrian di Bank & \\
\hline 14 & $\begin{array}{l}\text { Proses menginput mata kuliah untuk semester berikutnya } \\
\text { mudah }\end{array}$ & \\
\hline 15 & Tidak ada antrian saat menginput mata kuliah & \\
\hline
\end{tabular}




\begin{tabular}{|c|c|c|}
\hline No & Customer Need & Technical Response \\
\hline 16 & Nilai diberitahukan dengan rinci & Kinerja SDM \\
\hline 17 & Mudah dalam mendapatkan materi perkuliahan & \multirow{3}{*}{ Kemudahan Proses } \\
\hline 18 & Ruang dan waktu kuliah konsisten & \\
\hline 19 & $\begin{array}{l}\text { Ada pemberitahuan sebelumnya bila perkuliahan ditiadakan } \\
\text { atau diundur }\end{array}$ & \\
\hline 20 & $\begin{array}{l}\text { Adanya signage atau spanduk yang menunjukan adanya } \\
\text { gedung UAI }\end{array}$ & \multirow{2}{*}{ Kelengkapan Fasilitas } \\
\hline 21 & Tersedia proyektor yang layak untuk dipakai saat kuliah & \\
\hline 22 & Meja dan kursi kuliah yang nyaman & Fasilitas Memadai \\
\hline 23 & Tersedia ruang kelas yang sesuai dengan jumlah mahasiswa & Kesesuaian Jumlah Fasilitas \\
\hline 24 & AC yang selalu beroperasi dengan baik di ruang kelas & Kelengkapan Fasilitas \\
\hline 25 & Perpustakaan yang nyaman dan bersih & Fasilitas Memadai \\
\hline 26 & $\begin{array}{l}\text { Jumlah meja dan kursi sesuai jumlah pengunjung } \\
\text { perpustakaan }\end{array}$ & Kesesuaian Jumlah Fasilitas \\
\hline 27 & Koleksi buku untuk setiap jurusan lengkap & Kelengkapan Fasilitas \\
\hline 28 & $\begin{array}{l}\text { Ada perpustakaan yang dapat diakses lewat internet sehingga } \\
\text { memudahkan mahasiswa untuk mendapatkan data yang } \\
\text { diperlukan }\end{array}$ & \multirow{3}{*}{ Fasilitas Memadai } \\
\hline 29 & $\begin{array}{l}\text { Tersedia ruang diskusi yang nyaman dan (meja dan kursi) } \\
\text { memadai }\end{array}$ & \\
\hline 30 & Tersedia toilet yang bersih & \\
\hline 31 & Jumlah toilet yang memadai untuk mahasiswa pria & \multirow{2}{*}{ Kesesuaian Jumlah Fasilitas } \\
\hline 32 & Jumlah toilet yang memadai untuk mahasiswa wanita & \\
\hline 33 & Tersedia kantin yang besih & Fasilitas Memadai \\
\hline 34 & Jumlah meja dan kursi di kantin yang memadai & Kesesuaian Jumlah Fasilitas \\
\hline 35 & Makanan dan minuman yang ada di kantin bervariasi & Kelengkapan Fasilitas \\
\hline 36 & Tersedia hotspot untuk akses internet & Fasilitas Memadai \\
\hline
\end{tabular}




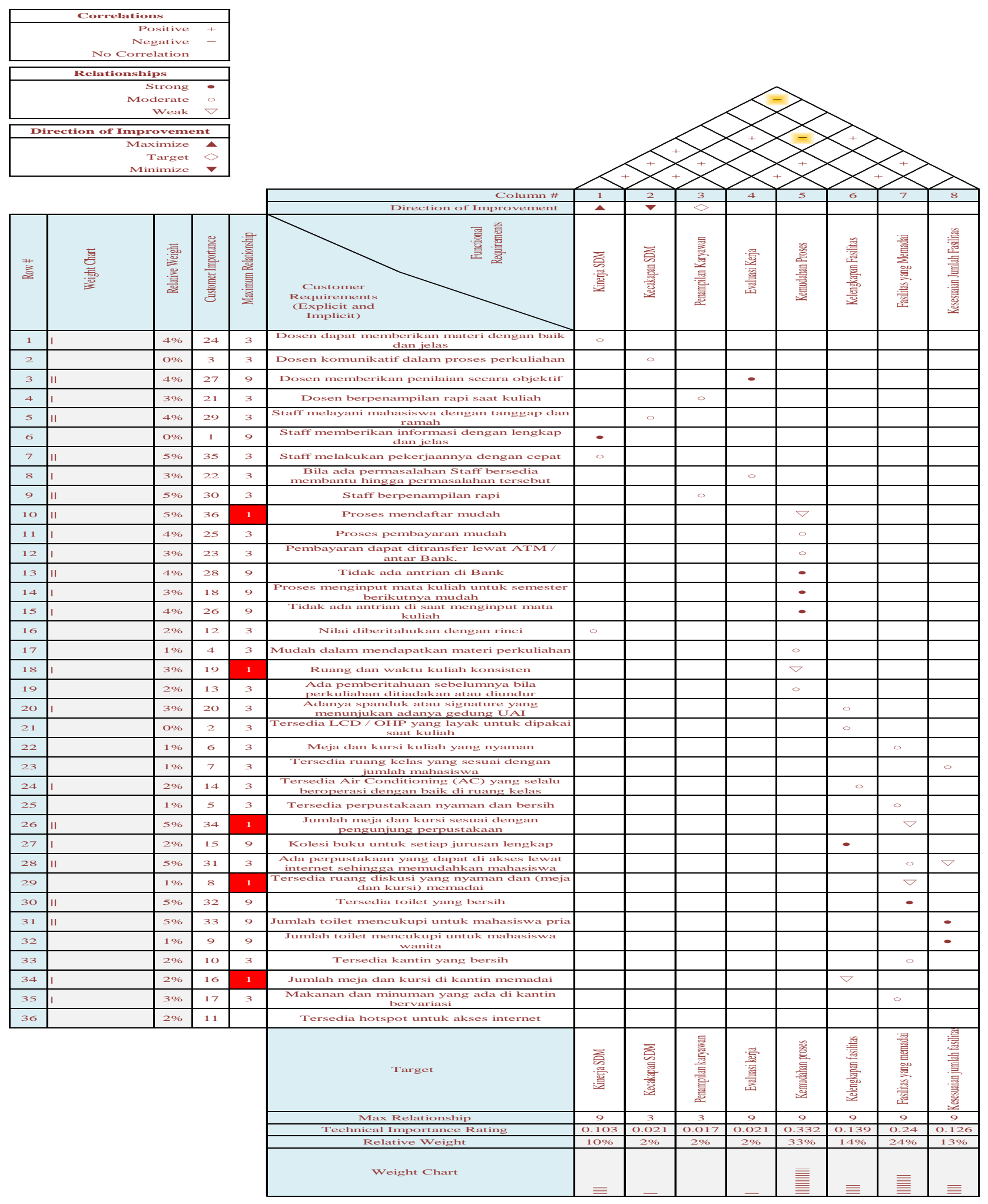

Gambar 2. House of Quality 